\title{
SELF-PERCEPTION OF ACADEMIC ABILITY SISWA SMA DI MASA PANDEMIK COVID-19: FAKTOR APA YANG MEMPREDIKSI?
}

\author{
Riska Umami Lia Sari ${ }^{1}$, Raja Oloan Tumanggor ${ }^{2}$, P. Tommy Y. S. Suyasa ${ }^{3}$ \\ ${ }^{1}$ Program Studi Magister Psikologi Profesi, Universitas Tarumanagara Jakarta \\ Email: riska.707191003@stu.untar.ac.id \\ ${ }^{2}$ Fakultas Psikologi, Universitas Tarumanagara Jakarta \\ Email: rajat@fpsi.untar.ac.id \\ ${ }^{3}$ Fakultas Psikologi, Universitas Tarumanagara Jakarta \\ Email:tommys@fpsi.untar.ac.id
}

Masuk : 12-06-2021, revisi: 26-09-2021, diterima untuk diterbitkan :09-10-2021

\begin{abstract}
Self-perception of academic ability is outlook that students have about their abilities in terms of learning activities or in completing school assignments. One of the reasons for the importance of self-perception of academic ability is to be a factor that can motivate students in learning activities. This study aims to determine whether self-perception of academic ability is predicted by the role of student burnout and student engagement. This study was conducted using convenience sampling on high school students during the Covid-19 Pandemic. The number of participants was 96 Tangerang City Senior High School students, aged 16 to 18 years. This study uses the School Attitude Assessment Survey-Revised to measure self-perception of academic ability, the Burnout Inventory to measure student burnout and the Utrecht Work Engagement Scale-9 to measure student engagement. Based on the test results using the multiple regression method, it was found that self-perception of academic ability was predicted significantly by student burnout $(\beta=-0.242)$ and student engagement $(\beta=0.564)$. With the results of this study, it is hoped that educators can anticipate learning activities to foster student engagement. With higher student engagement, students' self-perception of academic ability will be more positive. For students, the results of this study are expected as initial information to be more aware of the burnout conditions experienced. Burnout conditions can predict students' view of academic ability to be negative.
\end{abstract}

Keywords: Student engagement, student burnout, self-perception of academic ability, high school student, Covid-19

\begin{abstract}
ABSTRAK
Self-perception of academic ability merupakan pandangan yang dimiliki siswa mengenai kemampuan dalam hal kegiatan belajar atau dalam menyelesaikan tugas - tugas sekolah. Salah satu alasan pentingnya self-perception of academic ability yaitu menjadi faktor yang dapat memotivasi siswa dalam kegiatan pembelajaran. Penelitian ini bertujuan untuk mengetahui apakah self-perception of academic ability diprediksi oleh peran student burnout dan student engagement. Penelitian ini dilakukan dengan menggunakan convenience sampling pada siswa SMA di Masa Pandemik Covid-19. Jumlah partisipan sebesar 96 siswa SMA Kota Tangerang, berusia 16 hingga 18 tahun. Menggunakan alat ukur School Attitude Assessment Survey-Revised untuk mengukur self-perception of academic ability, alat ukur Maslach Burnout Inventory untuk mengukur student burnout dan untuk alat ukur Utrecht Work Engagement Scale-9 digunakan untuk mengukur student engagement. Berdasarkan hasil uji dengan menggunakan metode regresi berganda didapatkan hasil bahwa self-perception of academic ability diprediksi secara signifikan oleh student burnout $(\beta=-0.242)$ dan student engagement $(\beta=0.564)$. Dengan hasil penelitian ini diharapkan para pendidik dapat mengantisipasi dalam kegiatan belajar untuk menumbuhkan student engagement. Dengan student engagement yang semakin tinggi, self-perception of academic ability pada siswa akan semakin positif. Bagi siswa hasil penelitian ini diharapkan sebagai informasi awal agar lebih waspada terhadap kondisi burnout yang dialami. Kondisi burnout dapat memprediksi pandangan siswa terhadap kemampuan akademik menjadi negatif.
\end{abstract}

Kata Kunci: Student engagement, student burnout, self-perception of academic ability, siswa SMA, pandemik Covid19. 


\section{PENDAHULUAN}

\section{Latar Belakang}

Self-perception of academic ability adalah aspek yang sangat penting yang harus dimiliki oleh siswa dalam kegiatan pembelajaran. Salah satu alasan pentingnya self-perception of academic ability yaitu menjadi faktor yang dapat memotivasi siswa dalam kegiatan pembelajaran. Motivasi dalam kegiatan pembelajaran merupakan hal penting yang perlu dimiliki untuk memperoleh hasil yang baik (Deantono et al., 2012). Self-perception of academic ability merupakan bentuk persepsi kemampuan akademik pada siswa yang dapat mempengaruhi hasil dan memiliki peran dalam kegiatan pembelajaran. Siswa yang memiliki motivasi tinggi dan percaya diri akan lebih termotivasi dalam menyelesaikan tugas dan materi sulit yang diberikan (Bandura, 1994).

Proses terbentuknya persepsi ini berasal dari dua faktor yaitu faktor eksternal dan faktor internal. Faktor eksternal terdiri dari tiga tahap yaitu: pemilihan (selection), organisasi (organization), dan interpretasi (interpretation). Tahap pemilihan (selection) adalah ketika individu tertarik terhadap suatu hal. Lalu tahap organisasi (organization) yaitu ketika individu melakukan pengolahan informasi dari suatu hal yang menjadi pilihan. Tahap interpretasi (interpretation) yaitu ketika individu memeriksa atau membandingkan informasi yang dimilikinya dengan informasi yang dimiliki oleh orang lain. Faktor selanjutnya yaitu faktor internal; terdiri dari faktor fisiologis dan faktor psikologis. Faktor fisiologis meliputi kondisi penginderaan seperti mata, kulit, lidah, telinga, dan hidung. Dalam hal ini tidak semua individu memiliki kepekaan penginderaan yang sama. Selanjutnya faktor psikologis, yang terdiri dari motivasi dan pengalaman belajar masa lalu (Bem, 1972).

Self-perception of academic ability yang baik sangat dibutuhkan oleh siswa di masa pandemik saat ini. Adanya wabah Covid-19 yang terjadi berkepanjangan mengharuskan lembaga pendidikan termasuk sekolah di Indonesia melakukan strategi alternatif dalam rangka mencegah penyebaran virus Covid-19. Strategi yang dilakukan oleh lembaga pendidikan yaitu melakukan kegiatan Pembelajaran Jarak Jauh (PJJ) agar siswa tetap mendapatkan pendidikan sebagaimana mestinya. Hal ini disebabkan karena peran pendidik yang sangat penting dalam meningkatkan pendidikan siswa di sekolah.

Selama melakukan PJJ tidak sedikit siswa yang mengeluhkan kesulitannya seperti banyaknya tugas yang diterima dari seluruh pendidik, adanya keterbatasan waktu pengerjaan yang singkat dan membuat siswa menjadi kurang istirahat dan kelelahan. Keluhan tersebut disampaikan kepada Komisi Perlindungan Anak Indonesia (KPAI) dengan data yang KPAI dapatkan dari keluhan yang masuk, siswa sekolah menengah atas (SMA) menjadi responden terbanyak yang melakukan aduan (KPAI, 2020).

Sedangkan pada penelitian yang dilakukan oleh (Padli \& Rusdi, 2020) mengenai respons siswa sekolah menengah atas (SMP) dan SMA sederajat di Kota Makassar dalam pembelajaran online selama masa pandemik Covid-19 menunjukkan hasil bahwa siswa memberikan respons yang baik terhadap materi yang diberikan secara online dan hanya $2 \%$ siswa yang merespons kurang senang. Hal ini menunjukkan bahwa tidak sedikit siswa yang merespons positif terhadap pembelajaran daring (online) ini. Dapat diartikan bahwa siswa tersebut memiliki engagement yang baik, karena siswa merasa senang dan rasa memiliki yang kuat terhadap kegiatan pembelajaran yang akan menimbulkan motivasi dan ketekunan yang tinggi sehingga self-perception of academic ability pada siswa juga meningkat. 
Peneliti melakukan komunikasi personal kepada siswa SMA Kota Tangerang pada bulan Desember 2020, ada beberapa hal yang dikeluhkan siswa selama melakukan PJJ. Beberapa hal yang dikeluhkan siswa diantaranya, adanya keterbatasan komunikasi dengan pendidik dan teman kelas sebagai sumber informasi dan berbagi, adanya tuntutan lebih dalam mendapatkan nilai, kesulitan dalam mempelajari hal - hal baru di sekolah, dan sulitnya memiliki teman dekat. Menurut siswa, siswa merasakan dampak dari keluhan tersebut diantaranya siswa merasa menurunnya rasa ingin belajar dan merasa menjadi tidak percaya diri atas kemampuan yang dimiliki siswa.

Pada penelitian sebelumnya (Kaur et al., 2020) yang dilakukan pada mahasiswa farmasi diketahui bahwa terdapat hubungan antara burnout, engagement, dan perception of academic ability. Berdasarkan penelitian tersebut diketahui bahwa hubungan dimensi-dimensi burnout dengan perception of academic ability tampak lebih besar; dibandingkan dengan hubungan dimensidimensi engagement dengan perception of academic ability. Hal ini dapat diinterpretasikan bahwa perception of academic ability pada mahasiswa farmasi lebih diprediksi oleh faktor burnout dibandingkan dengan faktor engagement. Implikasinya adalah perception of academic ability yang semakin tinggi dapat diprediksi oleh kondisi-kondisi mahasiswa farmasi yang tidak mengalami kejenuhan (burnout) sedangkan usaha untuk meningkatkan engagement belum optimal dalam memprediksi perception of academic ability, hal ini terlihat dari tiga dimensi engagement hanya satu dimensi yang memprediksi perception of academic ability.

Pada penelitian Kaur et al. (2020), sudah dijelaskan bahwa adanya hubungan antara burnout, engagement, dan perception of academic ability pada mahasiswa farmasi dan tidak dilakukan pada kondisi pandemik Covid-19. Peneliti akan menguji hal - hal yang belum terjelaskan dari penelitian sebelumnya, yaitu penelitian dilakukan pada siswa SMA sebagai partisipan dan dilakukan pada kondisi pandemik Covid-19, serta adanya perbedaan tingkat burnout dan engagement antara mahasiswa farmasi dengan siswa SMA yang sedang menghadapi kondisi pandemik Covid-19.

Berdasarkan permasalahan diatas, maka peneliti tertarik untuk melakukan penelitian peran student burnout dan student engagement dalam memprediksi self-perception of academic ability pada siswa SMA Kota Tangerang di masa pandemik Covid-19.

\section{Rumusan Masalah}

Berdasarkan latar belakang masalah maka permasalahan pada penelitian ini dirumuskan sebagai berikut: apakah student burnout dan student engagement dapat memprediksi self-perception of academic ability pada siswa SMA Kota Tangerang di masa pandemik Covid-19?

\section{Peran Student Burnout dan Student Engagement dalam Memprediksi Self-Perception Of Academic Ability.}

Self-perception of academic ability adalah pandangan siswa terhadap kemampuannya dalam kegiatan akademik; pandangan ini berpengaruh dalam mengembangkan kepercayaan diri untuk terlibat dalam kegiatan akademik (Ames et al., dalam McCoach \& Siegle, 2003). Self-perception muncul dari mengamati tingkah laku diri sendiri dan mengamati tingkah laku lingkungan sekitar (Bem, 1967). Seseorang telah memiliki self-perception sejak usia dini, namun persepsi tidak muncul dengan sendirinya, melainkan melalui proses interaksi dari orang lain atau orang tua (Bem, 1972). Pada siswa SMA self-perception of academic ability adalah pandangan siswa terhadap kemampuan akademik yang dimilikinya. Terkait dengan kepercayaan diri dalam menyelesaikan tugas-tugas sekolah. 
Burnout merupakan kondisi tidak menyenangkan yang ingin diubah atau diperbaiki oleh individu ataupun organisasi (Maslach \& Leiter, 2008). Burnout pada siswa atau yang dikenal sebagai student burnout adalah perasaan lelah yang dirasakan oleh siswa karena adanya tuntutan belajar, bersikap sinis, adanya perasaan tidak kompeten sebagai siswa dan tidak peduli terhadap pelajaran (Schaufeli et al., 2002). Sindrom burnout pernah diteliti pada mahasiswa. Dalam penelitian burnout pada mahasiswa (Kaur et al., 2020), burnout dapat memprediksi self-perception of academic ability.

$\mathrm{H}_{1}$ : Student burnout dapat memprediksi self-perception of academic ability. Semakin rendah burnout semakin positif self-perception of academic ability.

Engagement didefinisikan sebagai keadaan pikiran yang selalu terkait atau ada perasaan memiliki tugas dan pekerjaan (Kaur et al, 2020). Student engagement merupakan bentuk perilaku siswa yang mempunyai keinginan dan usaha untuk terlibat dalam kegiatan pembelajaran dan berkontribusi pada hasil yang berhasil (Trowler, 2010). Selain itu student engagement menjadi komponen penting karena berhubungan dengan prestasi siswa di sekolah dan juga mempengaruhi sikap siswa dalam mematuhi aturan sekolah serta mempengaruhi kemampuan siswa untuk mengurangi kenakalan pada remaja (Galugu \& Samsinar, 2019). Bagi siswa yang memiliki engagement tinggi akan memiliki semangat dan kesediaan meluangkan pikiran sehubungan tugas-tugas sekolah yang dimilikinya. Tanpa disadari siswa menghabiskan waktu atau terlarut (absorb) dalam usaha menyelesaikan tugas-tugas sekolah. Penyelesaian tugas-tugas sekolah membuat siswa berpandangan positif terhadap kemampuan akademik yang dimilikinya.

$\mathrm{H}_{2}$ : Student engagement dapat memprediksi self-perception of academic ability. Semakin tinggi student engagement semakin positif self-perception of academic ability.

\section{METODE PENELITIAN \\ Partisipan penelitian}

Partisipan pada penelitian ini yaitu siswa SMA aktif di wilayah Kota Tangerang yang melakukan pembelajaran jarak jauh/ daring/ online. Berjenis kelamin laki-laki dan perempuan, berusia antara 16 hingga 18 tahun. Untuk mendapatkan partisipan dalam penelitian ini, peneliti melakukan penyebaran link kuesioner melalui grup siswa SMA di media sosial dan hanya sebanyak 137 siswa yang mengisi link kuesioner hal ini dikarenakan adanya keterbatasan waktu, biaya dan kondisi pandemik dalam menyelesaikan penelitian ini sehingga jumlah partisipan belum mencapai jumlah yang diharapkan. Selanjutnya, peneliti melakukan validasi data melalui software SPSS versi 22 dari 137 siswa yang mengisi link kuesioner, hanya sebanyak 96 siswa yang memiliki data valid. Jumlah siswa dengan kelamin laki - laki sebanyak 13 orang dan perempuan sebanyak 83 orang. Siswa dari jurusan IPA sebanyak 58 dan jurusan IPS sebanyak 38. Partisipan terbanyak berasal dari kelas XII.

\section{Pengukuran}

Penelitian ini dilakukan dengan menggunakan kuesioner berbasis google form. Link google form kemudian disebarkan kepada pada siswa SMA Kota Tangerang yang berstatus aktif melalui media sosial (Whatsapp). Google form dalam penelitian ini berisi alat ukur untuk mengukur: (a) selfperception of academic ability, (b) student burnout, dan (c) student engagement. 
Self-perception of academic ability diukur dengan Student Attitude Assessment Survey-Revised atau SAAS-R (McCoach \& Siegle, 2003) yang telah diadaptasi oleh penulis. Skala SAAS-R terdiri dari 7 butir pernyataan yang disusun dalam bentuk pernyataan tertutup. Contoh butir pernyataan: "saya cerdas, saya dapat mempelajari ide - ide baru dengan cepat di sekolah". Metode pengukuran menggunakan sumative rating scale yang memiliki rentang 1 hingga 7 . Koefisien reliabilitas internal (cronbach's alpha) dari 7 butir pernyataan SAAS-R tersebut adalah sebesar 0.877 .

Student burnout diukur dengan Maslach Burnout Inventory-Student Survey atau MBI-SS (Maslach et al., 2018). Terdapat tiga dimensi pada MBI-SS yaitu emotional exhaustion, cynicism, dan reversed professional efficacy. Skala MBI-SS terdiri dari 16 butir pernyataan yang disusun dalam bentuk pernyataan tertutup. Contoh butir (emotional exhaustion): "secara emosional, saya merasa terbebani oleh sekolah online, saya merasa sangat lelah setelah belajar online seharian". Contoh butir (cynicism): "Saya hanya ingin menyelesaikan tugas saya dan tidak diganggu oleh apapun, Saya menjadi tidak yakin apakah tugas sekolah bermanfaat (berguna) bagi saya. ".Contoh butir (reversed professional efficacy): "Saya menjadi kurang antusias terhadap pelajaran - pelajaran saya, Saya merasa lelah akibat pelajaran - pelajaran saya". Metode pengukuran menggunakan sumative rating scale yang memiliki rentang 0 hingga 6 . Koefisien reliabilitas internal (cronbach's alpha) pada dimensi emotional exhaustion sebesar 0.928; dimensi cynicism sebesar 0.753; dan dimensi reversed professional efficacy sebesar 0.829 .

Student engagement diukur dengan Utrecht Work Engagement Scale - 9 atau UWES-9 (Schaufeli et al., 2006). UWES-9 memiliki tiga dimensi diantaranya vigor, dedication, dan absorbtion. Skala UWES-9 terdiri dari 9 butir pernyataan yang disusun dalam bentuk pernyataan tertutup. Contoh butir (vigor): "di sekolah online, saya merasa penuh energi, di sekolah online, saya merasa kuat dan bersemangat". Contoh butir (dedication): "saat saya bangun di pagi hari, saya merasa ingin mengikuti sekolah online, saya antusias dengan jurusan saya". Contoh butir (absorbtion): "saya bangga (senang / puas) dengan prestasi saya di sekolah, saya menikmati / terlarut-dalam tugas / pekerjaan sekolah (Jurusan: IPA/ IPS/ dll)". Metode pengukuran menggunakan sumative rating scale yang memiliki rentang 0 hingga 6 . Kemudian peneliti melakukan uji reliabilitas setiap dimensi. Koefisien reliabilitas internal (cronbach's alpha) pada dimensi vigor sebesar 0.886; dedication sebesar 0.814; dan absorbtion sebesar 0.778 .

\section{HASIL DAN PEMBAHASAN}

Berdasarkan hasil analisis dengan menggunakan metode deskriptif statistik dapat dilihat pada Tabel 1, rata-rata burnout dan engagement pada siswa SMA Kota Tangerang.

\section{Tabel 1}

Gambaran Student Burnout dan Student Engagement Partisipan

\begin{tabular}{ccc} 
Scale & $\begin{array}{c}\text { Average Scare (SD) } \\
\text { Skala (0-30) }\end{array}$ & $\begin{array}{c}\text { Mean (SD) } \\
\text { Skala (0-6) }\end{array}$ \\
\hline Maslach Burnout Inventory & & \\
Emotional Exhaustion & $19.4(7.1)$ & $3.9(1.4)$ \\
Cynicism & $18.6(5.8)$ & $3.10(1.2)$ \\
Reversed Professional Efficacy & $11.7 \quad(6.0)$ & $1.9(1.0)$ \\
Utrecht Work Engagement & Skala (0-18) & Skala (0-6) \\
Vigor & $8.6(3.6)$ & $2.9(1.2)$ \\
Dedication & $12.1(3.9)$ & $4.0(1.3)$ \\
Absorption & $9.6(3.8)$ & $3.2(1.3)$ \\
\hline
\end{tabular}


Berdasarkan Tabel 1 skor rata - rata siswa pada variabel student burnout terdapat dua dimensi yang tergolong di atas titik tengah alat ukur atau cenderung tinggi yaitu dimensi emotional exhaustion yaitu sebesar 19.4 dengan standar deviasi 7.1 pada skala 0 sampai 30 dan dimensi Cynicism dengan standar deviasi 5.8 pada skala 0 sampai 30. Skor rata-rata dimensi tersebut. Artinya secara emosional, partisipan cenderung merasa terbebani oleh sekolah online, partisipan cenderung merasa lelah setelah belajar online seharian sehingga menimbulkan siswa bersikap sinis terhadap hal - hal yang berhubungan dengan kegiatan sekolah.

Berdasarkan Tabel 1 skor rata - rata tertinggi siswa pada variabel student engagement hanya terdapat pada dimensi dedication yaitu 12.1 dengan standar deviasi 3.9 pada skala 0 sampai 18 . Skor rata-rata dimensi tersebut tergolong di atas titik tengah alat ukur atau cenderung tinggi. Artinya partisipan merasa tetap ingin mengikuti sekolah online, partisipan tetap antusias dengan jurusannya.

Berdasarkan uraian diatas dapat dijelaskan bahwa variabel student burnout memprediksi selfperception of academic ability pada siswa SMA secara negatif dan student engagement memprediksi self-perception of academic ability pada siswa SMA secara positif.

Selanjutnya peneliti melakukan uji hipotesis dengan melakukan uji regresi berganda yang dapat dilihat pada Tabel 2.

\section{Tabel 2}

Pengujian Hipotesis Peran Student Burnout dan Student Engagement sebagai Prediktor Selfperception of Academic Ability

\begin{tabular}{|c|c|c|c|c|c|c|}
\hline \multirow[t]{2}{*}{ Model } & & \multicolumn{2}{|c|}{ Unstandardized Coefficients } & \multirow{2}{*}{$\begin{array}{l}\text { Standardized } \\
\text { Coefficients } \\
\text { Beta }\end{array}$} & \multirow[t]{2}{*}{$\mathbf{T}$} & \multirow[t]{2}{*}{ Sig. } \\
\hline & & B & Std. Error & & & \\
\hline \multirow[t]{3}{*}{1} & (Constant) & 33.903 & 7.027 & & 4.824 & .000 \\
\hline & Student Burnout & -.242 & .082 & -.242 & -2.941 & .004 \\
\hline & Student Engagement & .564 & .082 & .564 & 6.860 & .000 \\
\hline
\end{tabular}

a.

Dependent Variable: Self-perception of academic ability

Berdasarkan Tabel 2, dengan menggunakan metode multiple regression analysis diperoleh nilai $\beta$ sebesar - 0.242 pada variabel student burnout dan 0.564 pada variabel student engagement. Artinya peran student burnout memprediksi self-perception of academic ability secara negatif sebesar $24.2 \%$ dan peran student engagement memprediksi self-perception of academic ability secara positif sebesar $56.4 \%$.

Berdasarkan keseluruhan hasil uji hipotesis maka peneliti menyimpulkan bahwa $\mathrm{H}_{1}$ dan $\mathrm{H}_{2}$ pada penelitian ini diterima. Peran student burnout memprediksi self-perception of academic ability secara negatif sebesar $24.2 \%$ maka semakin rendah burnout semakin positif self-perception of academic ability dan peran student engagement memprediksi self-perception of academic ability secara positif sebesar $56.4 \%$ maka semakin tinggi student engagement semakin positif selfperception of academic ability. 


\section{KESIMPULAN DAN SARAN}

Berdasarkan hasil penelitian ini, peneliti dapat disimpulkan bahwa student burnout berperan memprediksi self-perception of academic ability secara negatif sebesar $\beta=-0.242$. Sedangkan student engagement berperan memprediksi self-perception of academic ability secara positif sebesar $\beta=0.564$ yang dilakukan pada siswa SMA Kota Tangerang di masa pandemik Covid-19. Artinya semakin rendah burnout semakin positif self-perception of academic ability dan semakin tinggi student engagement semakin positif self-perception of academic ability.

Ada beberapa keterbatasan pada penelitian ini seperti dalam mengambil jumlah partisipan karena penelitian ini dilakukan pada masa pandemik Covid-19 sehingga tidak dapat bertemu langsung dengan partisipan untuk menjelaskan dan mendampingi pengisian kuesioner secara langsung untuk menghindari pengisian yang tidak menggambarkan jawaban yang sebenarnya, maka peneliti menyarankan untuk peneliti selanjutnya mengembangkan penelitian ini dengan memperluas jumlah dan karakteristik partisipan. Lalu peneliti juga menyarankan untuk penelitian selanjutnya lebih bervariatif dalam memperluas variabel bebas yang berkenaan dengan self-perception of academic ability. Selain itu peneliti selanjutnya disarankan untuk mendampingi partisipan dalam mengisi kuesioner seperti mengelompokkan partisipan dalam satu ruangan dan diawasi oleh peneliti untuk menghindari pengisian kuesioner yang tidak menggambarkan jawaban sebenarnya seperti yang terjadi pada penelitin ini dari 137 partisipan yang mengisi kuesioner hanya sebanyak 96 partisipan yang memiliki data valid. Lalu peneliti selanjutnya dapat melakukan penelitian pada populasi yang lebih luas dan penelitian tidak dilakukan pada masa pandemik Covid-19.

\section{Ucapan Terima Kasih (Acknowledgement)}

Peneliti mengucapkan terima kasih yang sebesar - besarnya kepada semua pihak yang telah berkontribusi dalam penyelesaian dan penulisan penelitian ini, terutama untuk partisipan penelitian.

\section{REFERENSI}

Bandura, A. (1994). Bandura Self-efficacy defined. In Encyclopedia of Human Behavior.

Bem, D. J. (1972). Self-Perception Theory. Advances in Experimental Social Psychology, 6(C), 1-62. https://doi.org/10.1016/S0065-2601(08)60024-6.

Bem, D. J. (1967). Self-perception: An alternative interpretation of cognitive dissonance phenomena. Psychological Review, 74(3), 183-200. https://doi.org/10.1037/h0024835.

Deantono, Y., Dariyo, A., \& Suyasa, P. T. Y. S. (2012). Gaya mengajar dan motivasi berprestasi siswa sekolah menengah atas (SMA). Provitae Jurnal Psikologi Pendidikan, 5(1), 1-21.

Galugu, N. S., \& Samsinar, S. (2019). Academic self-concept, teacher's supports and student's engagement in the school. Jurnal Psikologi Pendidikan Dan Konseling: Jurnal Kajian Psikologi Pendidikan dan Bimbingan Konseling, 5(2), 141. https://doi.org/10.26858/jppk.v5i2.10549

Kaur, M., Long, J. W., Luk, F. S., Mar, J., Nguyen, D. L., Ouabo, T., Singh, J., Wu, B., Rajagopalan, V., Schulte, M., \& Doroudgar, S. (2020). Relationship of burnout and engagement to pharmacy students' perception of their academic ability. American Journal of Pharmaceutical Education, 84(2), 213-216. https://doi.org/10.5688/ajpe7571

KPAI (Komisi Perlindungan Anak Indonesia, 2020). Ada 246 Aduan di KPAI soal Belajar Daring, Siswa Keluhkan Tugas Menumpuk-Kuota. KPAI.

Maslach, C. Jackson, S. E. \& Leiter, M. P. (2018). Maslach Burnout Inventory Manual [Paperback]. 81. http://www.amazon.com/Maslach-Burnout-Inventory-ManualChristina/dp/9996345777

Maslach, C., \& Leiter, M. P. (2008). Early predictors of job burnout and engagement. Journal of 
Applied Psychology, 93(3), 498-512. https://doi.org/10.1037/0021-9010.93.3.498

McCoach, D. B., \& Siegle, D. (2003). The school attitude assessment survey-revised: A new instrument to identify academically able students who underachieve. Educational and Psychological Measurement, 63(3), 414429.https://doi.org/10.1177/0013164403063003005

Padli, F., \& Rusdi. (2020). Respon siswa dalam pembelajaran online selama pandemi. Social Landscape Journal, 1(3), 1-7.

Schaufeli, W. B., Bakker, A. B., \& Salanova, M. (2006). The measurement of work engagement with a short questionnaire: A cross-national study. Educational and Psychological Measurement, 66(4), 701-716. https://doi.org/10.1177/0013164405282471

Schaufeli, W. B., Martínez, I. M., Pinto, A. M., Salanova, M., \& Barker, A. B. (2002). Burnout and engagement in university students a cross-national study. Journal of Cross-Cultural Psychology, 33(5), 464-481. https://doi.org/10.1177/0022022102033005003

Trowler, V. (2010). Student engagement literature review. Higher Education. 